\title{
Clinical Outcomes and Prognostic Factors of Fractionated Stereotactic Radiation Therapy for Large Brain Metastases as a Potential Alternative to Surgery
}

Hiroaki Ogawa ( $\sim$ hogawa@cick.jp)

Tokyo Metropolitan Cancer and Infectious Diseases Center Komagome Hospital: Tokyo Toritsu Komagome Byoin https://orcid.org/0000-0002-3298-1136

Kei Ito

Tokyo Metropolitan Cancer and Infectious Diseases Center Komagome Hospital: Tokyo Toritsu Komagome Byoin Katsuyuki Karasawa

Tokyo Metropolitan Cancer and Infectious Diseases Center Komagome Hospital: Tokyo Toritsu Komagome Byoin

\section{Research Article}

Keywords: fractionated stereotactic radiation therapy, large brain metastases, clinical outcomes, prognostic factors

Posted Date: May 6th, 2021

DOI: https://doi.org/10.21203/rs.3.rs-484218/v1

License: (c) (1) This work is licensed under a Creative Commons Attribution 4.0 International License. Read Full License 


\section{Abstract}

Introduction: We investigated the outcomes and prognostic factors for fractionated stereotactic radiation therapy (FSRT) for large brain metastases and evaluated whether FSRT could negate the need for surgery, which is the mainstream treatment for large brain metastases.

Methods: Patients with brain metastases measuring $\geq 2 \mathrm{~cm}$ treated with FSRT were retrospectively examined. Patients undergoing FSRT postoperatively were excluded. Local failure, intracranial failure, and adverse events were evaluated.

Results: Overall, 106 lesions in 98 patients were evaluated. Performance status was $0-1,2-4$, and unknown in 79, 25, and 2 patients, respectively. The median maximum tumor diameter was $25 \mathrm{~mm}$, and the median prescription dose was $35 \mathrm{~Gy}$ in 3 fractions. The median follow-up period after FSRT was 7 months. The 1 -year rates of local failure, intracranial failure, and overall survival were $13.0 \%, 57.8 \%$, and $48.0 \%$, respectively. In multivariate analysis, the maximum dose for target $\geq 135 \mathrm{~Gy}$ (biological equivalent dose of a/b of $10 \mathrm{~Gy}$ ) and good performance status were independent positive prognostic factors for local failure. Sixteen patients (16.3\%) were treated with whole-brain radiotherapy after FSRT owing to multiple intracranial recurrences, while surgery was performed for three patients (3.1\%) owing to local recurrence.

Conclusions: FSRT for large brain metastases achieved good local control and only $3 \%$ of patients needed surgery after FSRT, suggesting that FSRT is a potential alternative to surgery. In FSRT, a higher maximum tumor dose was useful for local control.

\section{Introduction}

Brain metastases (BMs) affect up to $30 \%$ of all patients with cancer and cause various neurological complications [1]. The incidence of BM is expected to increase further because of expanded screening efforts using magnetic resonance imaging (MRI) and improved systemic therapies [2]. The standard of care for BM is multimodality treatment including whole-brain radiotherapy (WBRT), stereotactic radiosurgery (SRS), and surgical resection [3, 4]. SRS provides good local control and is associated with lower cognitive dysfunction rates for intact BM $[5,6]$. By contrast, the risk of radiation toxicity increases with tumor size and target volume in SRS [7]; thus, the SRS dose for a large BM is typically forced to be lowered for safety [8]. Therefore, SRS treatment has been less effective in controlling large BMs than small tumors [9].

Surgery is usually performed particularly for large BMs because of the advantages of fast resolution of peritumoral edema and immediate reduction in tumor volume $[10,11]$. However, surgery has some disadvantages. Some cases involve a long postoperative recovery time, which adds to the burden of the surgery, resulting in delays in systemic therapy. Moreover, complications of surgery, such as infection and bleeding, although rare, can be fatal.

Fractionated stereotactic radiation therapy (FSRT) is an expansion technique of frameless SRS and is typically delivered using a linear accelerator. FSRT has the radiobiological advantage of fractionation of normal brain tissues, resulting in possible administration of higher doses to tumors than it can be achieved with single-fraction SRS. Therefore, FSRT is expected to reduce the risk of radiation necrosis (RN) while maintaining or improving local control for intact large BMs [2, 12-15]. Furthermore, FSRT is an effective and minimally invasive treatment for large BMs and can be a therapeutic option to facilitate the avoidance of surgery. In this study, we evaluated the treatment outcomes and investigated the prognostic factors for FSRT to identify cases where surgery could be avoided.

\section{Patients And Methods}




\section{Patients}

We retrospectively reviewed the medical records of patients who received FSRT for BM between February 2012 and December 2019 in a single Japanese institution. Patients were included if they met the following criteria: (i) diagnosed with BMs on MRI (or computed tomography [CT] in some patients), (ii) maximum diameter of $\mathrm{BM} \geq 2 \mathrm{~cm}$, (iii) treated with FSRT with three or five fractions, and (iv) tumor images of the targeted tumor were evaluated at least once after FSRT. We excluded patients who underwent surgery for the target lesion before FSRT. We performed surgery for cases with an expected prognosis $\geq 6$ months and a tumor with extensive edema or neurologic symptoms.

This study was approved by our institutional ethical review board (approval number 2487), and written informed consent was obtained from all patients.

\section{Treatments}

Patients were immobilized in the supine position and wore a thermoplastic mask. Treatment planning images were obtained with contrast-enhanced CT with a 1-mm slice thickness and contrast-enhanced T1 volumetric MRI sequences with a 1.3-mm slice thickness. The gross tumor volume (GTV) was defined as an abnormal contrast-enhanced lesion on CT and MRI. The clinical target volume was equal to GTV. A 1-mm margin was added to the clinical target volume to create the planning target volume (PTV). We prescribed an optimal prescription isodose line of approximately $70 \%$ before August 2014. From September 2014 onward, a 60\% isodose line was used for dose prescription. The prescribed dose covered $95 \%$ of the PTV. We aimed to prescribe $35 \mathrm{~Gy}$ in three fractions or $41.5 \mathrm{~Gy}$ in five fractions, provided that the surrounding brain tissue satisfied the dose constraints. The dose constraint was set for the surrounding brain tissue so that the volume received $23.1 \mathrm{~Gy}$ in three fractions or $28.8 \mathrm{~Gy}$ in five fractions was $<7 \mathrm{cc}$ by reference to a single-fraction dose equivalent of $14 \mathrm{~Gy}$ calculated in biological equivalent dose (BED) of a/b of $2 \mathrm{~Gy}\left(\mathrm{BED}_{2}\right)[16,17]$. All treatments were delivered using CyberKnife® (Accuray Inc., Sunnyvale, CA).

\section{Statistical analysis}

The primary endpoint of the present retrospective study was local failure (LF). Other endpoints were best tumor response, intracranial failure (ICF), overall survival, surgery for targeted lesion, and toxicities. Time to event date was calculated in months from the start date of FSRT. Tumor response was evaluated according to the Response Assessment in Neuro-Oncology Brain Metastases (RANO-BM) [18]. Initial response was recorded on MRI at 1-3 months after FSRT. LF was defined as a progressive disease of the target lesion according to RANO-BM. LF was estimated using the cumulative incidence function adjusted for the competing risk of death and compared using Gray's test for equality. For the multivariate analysis of LF, the Fine-Gray competing risks model was used for deriving the hazard ratio for all variables identified as significant in the univariate analysis. The overall survival rate was estimated using the Kaplan-Meier method. The results were considered significant for $p$ values $<0.05$. All statistical analyses were performed using EZR (Saitama Medical Center, Jichi Medical University, Saitama, Japan) [19].

\section{Results}

\section{Patient characteristics}

Among 821 lesions treated with stereotactic radiation therapy in our institution, 106 lesions in 98 patients were eligible for this study. The patient and tumor characteristics are shown in Table 1. Fifteen (15.3\%) patients underwent WBRT before FSRT. Twenty-one (19.8\%) lesions were larger than $30 \mathrm{~mm}$ in terms of the maximum tumor diameter. The median prescribed dose was $35 \mathrm{~Gy}$ in three fractions (range, 22.5-41.5 Gy in three to five fractions). Details of the dose characteristics are summarized in Table 2. 
Table 1

Patient characteristics

\begin{tabular}{|ll|}
\hline Characteristic & 106 cases from 98 patients \\
\hline Age (years) & $68(39-93)$ \\
\hline Median (range) & \\
\hline Sex & $57 / 41$ \\
\hline Male/Female & \\
\hline PS & $79 / 25 / 2$ \\
\hline $0-1 / 2-4$ /unknown & \\
\hline Primary lesion & 72 \\
\hline Lung & 15 \\
\hline Breast & 8 \\
\hline Colorectal & 11 \\
\hline Others & \\
\hline Number of brain metastases & $78 / 27 / 1$ \\
\hline $1 / 2-$ & $40 / 66$ \\
\hline Tumor maximum diameter (mm) & \\
\hline Median (range) & $25(20-50)$ \\
\hline Tumor volume (cc) & \\
\hline Median (range) & \\
\hline History of whole brain radiotherapy & \\
\hline Yes/No & \\
\hline Systemic therapy after FSRT & \\
\hline Yes/No/Unknown & \\
\hline PS, performance status, FSRT; fractionated stereotactic radiotherapy \\
\hline
\end{tabular}


Table 2

Dose and dosimetric characteristics

\begin{tabular}{|ll|}
\hline & Median (range) \\
\hline Prescription dose/fraction & $35 \mathrm{~Gy}$ in $3 \mathrm{fr} .(25-41.5 \mathrm{~Gy}$ in $3-5 \mathrm{fr}$.) \\
\hline Prescription dose, $\mathrm{BED}_{10}$ & $76 \mathrm{~Gy}(38-76 \mathrm{~Gy})$ \\
\hline Tumor marginal isodose line & $60 \%(50-95 \%)$ \\
\hline Maximum dose, $\mathrm{BED}_{10}$ & $148 \mathrm{~Gy}(49-188 \mathrm{~Gy})$ \\
\hline Mean dose, $\mathrm{BED}_{10}$ & $103 \mathrm{~Gy}(43-125 \mathrm{~Gy})$ \\
\hline Normal tissue $\mathrm{V}_{14}$ Gy equivalent & $6.2 \mathrm{cc}(0-22 \mathrm{cc})$ \\
\hline Normal tissue $\mathrm{V}_{12}$ Gy equivalent & $8.9 \mathrm{cc}(1.8-30 \mathrm{cc})$ \\
\hline$B E D_{10}$, biological equivalent dose of a/b of $10 \mathrm{~Gy}$ \\
\hline
\end{tabular}

\section{Clinical outcomes}

The median follow-up period was 7 months (range, 1-48 months). All patients completed the planned treatment without respite. No patients treated in the hospital required an extension of their hospital stay. Complete response, partial response, stable disease, and progressive disease occurred in 14,74, 17, and 1 case(s), respectively. LF was observed in 13 lesions during follow-up. The 6- and 12-month LF rates were $5.4 \%$ and $13.0 \%$, respectively (Fig. 1). The 12-month LF rate for BMs $\geq 3 \mathrm{~cm}$ was $25.1 \%$. ICF was confirmed in 54 patients. The median ICF time was 10.4 months, and the 6 - and 12 -month ICF rates were $30.1 \%$ and $57.8 \%$, respectively (Fig. 1 ). The median overall survival was 11.5 months (Fig. 2). Three patients (3.1\%) underwent surgery because of local recurrence 5-10 months after FSRT and 16 patients (16.3\%) underwent WBRT owing to the occurrence of multiple BMs after FSRT.

Univariate analysis showed that the factors associated with better prognostic factors for LF were maximum dose for PTV $\geq 135 \mathrm{~Gy}$ in BED of $\alpha / \beta$ of $10 \mathrm{~Gy}\left(\mathrm{BED}_{10}\right)$ and good performance status (PS). Neither maximum diameter nor prescribed dose correlated with LF in the univariate analysis (Table 3). In the multivariate analysis, a maximum dose for PTV $\geq 135$ Gy with BED $_{10}$ (Fig. 3) and a good PS were independent positive prognostic factors for LF (Table 4). 
Table 3

Univariate analysis

\begin{tabular}{|c|c|c|c|}
\hline & & 1-y local failure rate (\%) & $\mathrm{p}$ value \\
\hline \multirow[t]{2}{*}{ PS } & $0-1(n=79)$ & 9.2 & \multirow[t]{2}{*}{0.0422} \\
\hline & $2-(n=27)$ & 31.6 & \\
\hline \multirow[t]{2}{*}{ Maximum diameter } & $<30 \mathrm{~mm}(\mathrm{n}=85)$ & 11.6 & \multirow[t]{2}{*}{0.530} \\
\hline & $\geq 30 \mathrm{~mm}(\mathrm{n}=21)$ & 27.6 & \\
\hline \multirow[t]{2}{*}{ Number of brain metastases } & $<2(\mathrm{n}=40)$ & 12.9 & \multirow[t]{2}{*}{0.388} \\
\hline & $\geq 2(n=66)$ & 16.9 & \\
\hline \multirow[t]{2}{*}{ Systemic therapy after FSRT } & yes $(n=78)$ & 11.4 & \multirow[t]{2}{*}{0.316} \\
\hline & no $(n=27)$ & 20.2 & \\
\hline \multirow[t]{2}{*}{ Prescribed dose $\left(\mathrm{BED}_{10}\right)$} & $<75$ Gy $(\mathrm{n}=33)$ & 4.2 & \multirow[t]{2}{*}{0.317} \\
\hline & $\geq 75$ Gy $(n=73)$ & 16.3 & \\
\hline \multirow[t]{2}{*}{ Mean dose $\left(\mathrm{BED}_{10}\right)$} & $<100$ Gy $(n=45)$ & 23.3 & \multirow[t]{2}{*}{0.0729} \\
\hline & $\geq 100$ Gy $(n=61)$ & 9.5 & \\
\hline \multirow[t]{2}{*}{ Maximum dose $\left(\mathrm{BED}_{10}\right)$} & $<135$ Gy $(\mathrm{n}=41)$ & 26.7 & \multirow[t]{2}{*}{0.00402} \\
\hline & $\geq 135$ Gy $(n=65)$ & 6.0 & \\
\hline
\end{tabular}

Table 4

Multivariate analysis

\begin{tabular}{|llll|}
\hline & HR & $95 \% \mathrm{Cl}$ & P value \\
\hline $\begin{array}{l}\text { Performance status } \\
(0-1 \text { vs. } 2-4)\end{array}$ & 0.29 & $0.10-0.82$ & 0.02 \\
\hline $\begin{array}{l}\text { Maximum dose } \\
(\geq 135 \text { Gy BED }\end{array}$ vs. $<135$ Gy BED $\left._{10}\right)$ & 0.16 & $0.041-0.60$ & 0.007 \\
\hline$B E D_{10}$; biological effective dose of a/b of 10 Gy & & \\
\hline
\end{tabular}

There was no grade 3 or higher toxicity in the present study. RN was observed in $5(3.9 \%)$ lesions. The median time to RN was 18 months (range, 3-19 months). All RNs were clinically diagnosed by MRI based on observation over time. All patients with RN were asymptomatic and did not undergo surgery or biopsy. Grade 2 intracranial hemorrhage was identified in two (1.9\%) lesions, and both had tumor hemorrhage. 
Table 5

Content and results of previous studies of outcomes for fractionated stereotactic radiotherapy for large brain metastases

\begin{tabular}{|c|c|c|c|c|c|c|c|c|c|}
\hline & Study type & $\mathbf{n}$ & $\begin{array}{l}\text { Median } \\
\text { f/u }\end{array}$ & $\begin{array}{l}\text { Median } \\
\text { diameter }\end{array}$ & $\begin{array}{l}\text { Dose (Gy) } \\
\text { /fractions }\end{array}$ & $\begin{array}{l}\text { Isodose } \\
\text { line }\end{array}$ & $\begin{array}{l}\text { LC } \\
\text { rate }\end{array}$ & $\begin{array}{l}\text { RN } \\
\text { rate }\end{array}$ & $\begin{array}{l}\text { Prognostic } \\
\text { factor }\end{array}$ \\
\hline $\begin{array}{l}\text { Navarria } \\
\text { et al [1] }\end{array}$ & Retrospective & 102 & 14 mos & $2.9 \mathrm{~cm}$ & $\begin{array}{l}37 / 3 \\
32 / 4\end{array}$ & $80 \%$ & $\begin{array}{l}1-y \\
96 \%\end{array}$ & $5.8 \%$ & $\begin{array}{l}\text { KPS, } \\
\text { extracranial } \\
\text { control }\end{array}$ \\
\hline $\begin{array}{l}\text { Jeong et } \\
\text { al [2] }\end{array}$ & Retrospective & 38 & 10 mos & $\begin{array}{l}17.6 \mathrm{cc} \\
(>3 \mathrm{~cm})\end{array}$ & $35 / 3$ or 5 & $80 \%$ & $\begin{array}{l}1-y \\
87 \%\end{array}$ & $15.8 \%$ & $\begin{array}{l}\text { Prescription } \\
\text { dose }\end{array}$ \\
\hline $\begin{array}{l}\text { Inoue et } \\
\text { al [3] }\end{array}$ & Retrospective & 85 & $8 \mathrm{mos}$ & $12.6 \mathrm{cc}$ & $31 / 5$ & $58 \%$ & $\begin{array}{l}8-m \\
92.9 \%\end{array}$ & $2.6 \%$ & NA \\
\hline $\begin{array}{l}\text { Inoue et } \\
\text { al [4] }\end{array}$ & Retrospective & 159 & $7 \mathrm{mos}$ & $6.9 \mathrm{cc}$ & $27 / 3$ & $60 \%$ & $\begin{array}{l}7-m \\
95.8 \%\end{array}$ & $2.1 \%$ & NA \\
\hline $\begin{array}{l}\text { Murai et } \\
\text { al [5] }\end{array}$ & Prospective & 61 & NA & $\begin{array}{l}\text { NA } \\
(>2.5 \\
\mathrm{cm})\end{array}$ & NA & NA & $\begin{array}{l}1-y \\
69 \%\end{array}$ & NA & NA \\
\hline $\begin{array}{l}\text { Marcrom } \\
\text { et al [6] }\end{array}$ & Retrospective & 182 & $5 \mathrm{mos}$ & $1.68 \mathrm{~cm}$ & $\begin{array}{l}25 \text { or } \\
30 / 5\end{array}$ & NA & $\begin{array}{l}1-y \\
86 \%\end{array}$ & $6 \%$ & $\begin{array}{l}\text { Smaller } \\
\text { tumor size, } \\
\text { higher } \\
\text { prescription } \\
\text { dose }\end{array}$ \\
\hline $\begin{array}{l}\text { Minniti } \\
\text { et al [7] }\end{array}$ & Retrospective & 138 & 29 mos & $\begin{array}{l}\text { NA } \\
(>2 \mathrm{~cm})\end{array}$ & $27 / 3$ & $\begin{array}{l}80- \\
90 \%\end{array}$ & $\begin{array}{l}1-y \\
90 \%\end{array}$ & $8 \%$ & $\begin{array}{l}\text { Non- } \\
\text { melanoma }\end{array}$ \\
\hline $\begin{array}{l}\text { Current } \\
\text { study }\end{array}$ & Retrospective & 106 & $7 \mathrm{mos}$ & $2.5 \mathrm{~cm}$ & $35 / 3$ & $60 \%$ & $\begin{array}{l}1-y \text { LF } \\
13.0 \%\end{array}$ & $3.9 \%$ & $\begin{array}{l}\text { PS, } \\
\text { maximum } \\
\text { tumor dose }\end{array}$ \\
\hline
\end{tabular}

$f / u$, follow up, $L C$, local control, $R N$; radiation necrosis, $K P S$, karnofsky performance status, $N A$; not applicable, $P S$, performance status, $L F$; local failure

1. Navarria P, Pessina F, Cozzi L, Ascolese AM, De Rose F, Fogliata A, Franzese C, Franceschini D, Tozzi A, D'Agostino G, Comito T, Iftode C, Maggi G, Reggiori G, Bello L, Scorsetti M (2016) Hypo-fractionated stereotactic radiotherapy alone using volumetric modulated arc therapy for patients with single, large brain metastases unsuitable for surgical resection. Radiat Oncol 11: 76 doi:10.1186/s13014-016-0653-3

2. Jeong WJ, Park JH, Lee EJ, Kim JH, Kim CJ, Cho YH (2015) Efficacy and Safety of Fractionated Stereotactic Radiosurgery for Large Brain Metastases. J Korean Neurosurg Soc 58: 217-224 doi:10.3340/jkns.2015.58.3.217

3. Inoue HK, Sato H, Seto K, Torikai K, Suzuki Y, Saitoh J, Noda SE, Nakano T (2014) Five-fraction CyberKnife radiotherapy for large brain metastases in critical areas: impact on the surrounding brain volumes circumscribed with a single dose equivalent of $14 \mathrm{~Gy}$ (V14) to avoid radiation necrosis. J Radiat Res 55: 334-342 doi:10.1093/jrr/rrt127

4. Inoue HK, Seto K, Nozaki A, Torikai K, Suzuki Y, Saitoh J, Noda SE, Nakano T (2013) Three-fraction CyberKnife radiotherapy for brain metastases in critical areas: referring to the risk evaluating radiation necrosis and the surrounding brain volumes circumscribed with a single dose equivalence of 14 Gy (V14). J Radiat Res 54: 727-735 doi:10.1093/jrr/rrt006

5. Murai T, Ogino H, Manabe Y, Iwabuchi M, Okumura T, Matsushita Y, Tsuji Y, Suzuki H, Shibamoto Y (2014) Fractionated stereotactic radiotherapy using CyberKnife for the treatment of large brain metastases: a dose escalation study. Clin Oncol (R Coll Radiol) 26: 151-158 doi:10.1016/j.clon.2013.11.027 


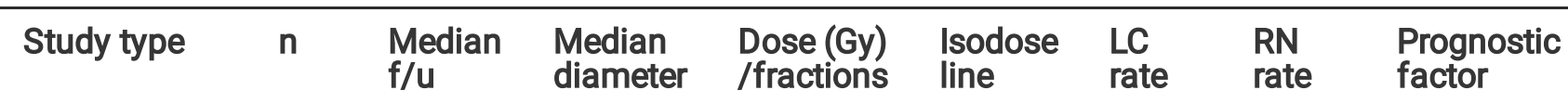

6. Marcrom SR, McDonald AM, Thompson JW, Popple RA, Riley KO, Markert JM, Willey CD, Bredel M, Fiveash JB (2017) Fractionated stereotactic radiation therapy for intact brain metastases. Adv Radiat Oncol 2: 564-571 doi:10.1016/j.adro.2017.07.006

7. Minniti G, Scaringi C, Paolini S, Lanzetta G, Romano A, Cicone F, Osti M, Enrici RM, Esposito V (2016) SingleFraction Versus Multifraction ( $3 \times 9$ Gy) Stereotactic Radiosurgery for Large (>2 cm) Brain Metastases: A Comparative Analysis of Local Control and Risk of Radiation-Induced Brain Necrosis. Int $J$ Radiat Oncol Biol Phys 95: 1142-1148 doi:10.1016/j.ijrobp.2016.03.013

\section{Discussion}

This study showed that FSRT for large BMs resulted in good local control. Only $3 \%$ of patients received surgery due to local recurrence after FSRT. No grade 3 or higher toxicities were observed, and no patients required an extension of hospital stay. These findings suggest that FSRT has the potential to be an alternative to surgery in terms of its low LF rate and low toxicity rate. In addition, a higher maximum dose for PTV was useful for local control.

While some reports have shown good clinical outcomes of FSRT alone for large BMs (Table 5) [14, 16, 17, 20-23], surgery is regarded as the mainstay treatment strategy for large BMs [24], as surgical resection has been considered a more reliable method than radiotherapy for reversing neurological deficits [8]. Although surgical resection can lead to fast resolution of peritumoral edema and immediately reduce the tumor volume [10,11], a surgical approach sometimes involves a waiting time for surgery and a postoperative recovery time in addition to the burden of surgery. Compared with surgery, FSRT alone has an overall shorter treatment time and is less invasive. These factors make it a good option for patients who need to receive systemic therapy following local treatment for BM. In this cohort, patients not candidates for surgery because of their prognosis or had a waiting time for surgery were included. Only three patients (3.1\%) required surgery 5-10 months after FSRT. In other words, most cases in this study achieved local control and were able to avoid surgery.

Conversely, FSRT has some disadvantages such as delay in the resolution of peritumoral edema or the shrinkage of tumor volume and the characteristics of radiotherapy that induce edema. Therefore, one goal of the present study was to identify the patients suitable for surgery and those who could be allowed to receive FSRT alone. We showed that a good PS and high maximum dose for PTV were correlated with a low LF rate. However, PS is thought to be a prognostic factor but not a predictive factor; therefore, PS cannot be used as an independent decision-making criterion between surgery and FSRT.

Regarding the maximum dose for PTV, the present data suggest that a higher maximum dose is appropriate for FSRT. Although it is unclear why the maximum dose relates to local control, a few studies have reported a correlation between the maximum tumor dose and local control $[25,26]$. In the report of RTOG $90-05$, patients treated with a linear accelerator were more likely to have local progression than those treated by a gamma-knife procedure [27]. In gammaknife SRS, a $50 \%$ isodose line is usually used for dose prescription, and in linear-accelerator SRS, a $60-90 \%$ isodose line is usually used for dose prescription. Compared with linear-accelerator SRS, gamma-knife SRS can typically deliver a higher maximum dose to the target. The same report mentioned that the hypoxic and more radioresistant portion of the tumor is located in the center of the tumor; hence, a higher maximum dose resulted in better local control. Even if the prescription dose is low because of the dose for the surrounding normal brain tissue, it is not a difficult technique to escalate the maximum dose in large BM; therefore, this is useful in daily clinical situations. 
We used two uniform dose constraints for normal tissue of $23.1 \mathrm{~Gy}$ in 3 fractions or $28.8 \mathrm{~Gy}$ in 5 fractions $<7 \mathrm{cc}$ by reference to a single dose equivalent of $14 \mathrm{~Gy}$ calculated in $B E D_{2}$, resulting in five cases of asymptomatic (grade 1) RN (3.9\%). No patients required surgery because of RN. A systematic review recommended the dose constraints for normal tissue of $23 \mathrm{~Gy}$ in 3 fractions and $29 \mathrm{~Gy}$ in 5 fractions $<20 \mathrm{cc}$ and estimated the rate of grade $3 \mathrm{RN}$ to be $3.4 \%$ and the rate of $\mathrm{RN}$ that required surgery to be $0 \%$ [28]. The dose constraints we used, therefore, are considered safe and reproducible.

The present study has some limitations. First, there were inevitable selection biases in this retrospective study. Treatment decisions of surgery or FSRT may have been affected by clinicians' intentions. Caution is needed to interpret these results, and these results might not be applicable to all large BM cases. Conversely, these results would adapt for the cases without strong edema or neurologic symptoms. Second, neither the prescription dose nor the prescription isodose line was unified. It is difficult to unify the prescription dose for large BMs owing to the prescription dose that depend on the dose constraints for normal brain tissue. However, the dose constraint for normal brain tissue was uniformed. Third, patients with $\mathrm{BM} \geq 3 \mathrm{~cm}$ were not the majority $(19.8 \%)$ in this cohort. Because of the small sample size of patients with $B M s \geq 3 \mathrm{~cm}$, this may have limited the detection of significant differences in clinical outcomes. Further research is required for larger BMs.

In conclusion, we showed the outcomes of FSRT for large BMs with low LF rates and acceptable toxicities in this study. Only $3 \%$ of patients needed surgery for the targeted lesion after FSRT. The study results suggest that FSRT for large BMs has the potential to be an alternative to surgery, at least as a good alternative treatment option for cases without extensive edema or neurologic symptoms. In this clinical setting, a maximum tumor dose of $\geq 135$ Gy in $B E D_{10}$ is important for tumor control.

\section{Declarations}

\section{Acknowledgments}

None.

\section{Declarations}

Funding. None.

Conflicts of interest/Competing Interests. The authors state that they have no conflicts of interest.

Availability of data and material: The datasets generated during and/or analysed during the current study are available from the corresponding author on reasonable request.

Code availability: Not applicable

Author contributions: H.O.; Designed and performed experiments, analyzed data and wrote the paper. K.I.; Designed experiments and co-wrote the paper. K.K.; Supervised the research.

Ethics approval: Approval was obtained from the ethics committee of Tokyo metropolitan Komagome hospital. The procedures used in this study adhere to the tenets of the Declaration of Helsinki.

Consent to participate: Individually informed consent was waived given the retrospective non-invasive nature of the study. 


\section{References}

1. Kotecha R, Gondi V, Ahluwalia MS, Brastianos PK, Mehta MP (2018) Recent advances in managing brain metastasis. F1000Res 7 doi:10.12688/f1000research.15903.1

2. Lehrer EJ, Peterson JL, Zaorsky NG, Brown PD, Sahgal A, Chiang VL, Chao ST, Sheehan JP, Trifiletti DM (2019) Single versus Multifraction Stereotactic Radiosurgery for Large Brain Metastases: An International Meta-analysis of 24 Trials. Int J Radiat Oncol Biol Phys 103:618-630. doi:10.1016/j.ijrobp.2018.10.038

3. Mahajan A, Ahmed S, McAleer MF, Weinberg JS, Li J, Brown P, Settle S, Prabhu SS, Lang FF, Levine N, McGovern S, Sulman E, McCutcheon IE, Azeem S, Cahill D, Tatsui C, Heimberger AB, Ferguson S, Ghia A, Demonte F, Raza S, Guha-Thakurta N, Yang J, Sawaya R, Hess KR, Rao G (2017) Post-operative stereotactic radiosurgery versus observation for completely resected brain metastases: a single-centre, randomised, controlled, phase 3 trial. The Lancet Oncology 18:1040-1048. doi:10.1016/s1470-2045(17)30414-x

4. Brown PD, Ballman KV, Cerhan JH, Anderson SK, Carrero XW, Whitton AC, Greenspoon J, Parney IF, Laack NNI, Ashman JB, Bahary J-P, Hadjipanayis CG, Urbanic JJ, Barker FG, Farace E, Khuntia D, Giannini C, Buckner JC, Galanis E, Roberge D (2017) Postoperative stereotactic radiosurgery compared with whole brain radiotherapy for resected metastatic brain disease (NCCTG N107C/CEC·3): a multicentre, randomised, controlled, phase 3 trial. The Lancet Oncology 18:1049-1060. doi:10.1016/s1470-2045(17)30441-2

5. Yamamoto M, Serizawa T, Shuto T, Akabane A, Higuchi Y, Kawagishi J, Yamanaka K, Sato Y, Jokura H, Yomo S, Nagano O, Kenai H, Moriki A, Suzuki S, Kida Y, Iwai Y, Hayashi M, Onishi H, Gondo M, Sato M, Akimitsu T, Kubo K, Kikuchi Y, Shibasaki T, Goto T, Takanashi M, Mori Y, Takakura K, Saeki N, Kunieda E, Aoyama H, Momoshima S, Tsuchiya K (2014) Stereotactic radiosurgery for patients with multiple brain metastases (JLGK0901): a multiinstitutional prospective observational study. The Lancet Oncology 15:387-395. doi:10.1016/s14702045(14)70061-0

6. Yamamoto M, Serizawa T, Higuchi Y, Sato Y, Kawagishi J, Yamanaka K, Shuto T, Akabane A, Jokura H, Yomo S, Nagano O, Aoyama H (2017) A Multi-institutional Prospective Observational Study of Stereotactic Radiosurgery for Patients With Multiple Brain Metastases (JLGK0901 Study Update): Irradiation-related Complications and Longterm Maintenance of Mini-Mental State Examination Scores. Int J Radiat Oncol Biol Phys 99:31-40. doi:10.1016/j.jjrobp.2017.04.037

7. Sneed PK, Mendez J, Vemer-van den Hoek JG, Seymour ZA, Ma L, Molinaro AM, Fogh SE, Nakamura JL, McDermott MW (2015) Adverse radiation effect after stereotactic radiosurgery for brain metastases: incidence, time course, and risk factors. J Neurosurg 123:373-386. doi:10.3171/2014.10.JNS141610

8. Chao ST, Salles AD, Hayashi M, Levivier M, Ma L, Martinez R, Paddick I, Régis J, Ryu S, Slotman BJ, Sahgal A (2018) Stereotactic Radiosurgery in the Management of Limited (1-4) Brain Metasteses: Systematic Review and International Stereotactic Radiosurgery Society Practice Guideline. Neurosurgery 83:345-353.

doi:10.1093/neuros/nyx522

9. Vogelbaum MA, Angelov L, Lee SY, Li L, Barnett GH, Suh JH (2006) Local control of brain metastases by stereotactic radiosurgery in relation to dose to the tumor margin. J Neurosurg 104:907-912. doi:10.3171/jns.2006.104.6.907

10. Patchell RA, Tibbs PA, Walsh HW, J.Dempsey R, Maruyama Y, Kryscio RJ, Markesbery WR, Macdonald JS, Young B (1990) A randomized trial of surgery in the treatment of single metastases to the brain. N Engl J Med 322:494500. doi:10.1056/NEJM199002223220802

Page $10 / 14$ 
11. Shimony N, Shofty B, Harosh CB, Sitt R, Ram Z, Grossman R (2017) Surgical Resection of Cerebral Metastases Leads to Faster Resolution of Peritumoral Edema than Stereotactic Radiosurgery: A Volumetric Analysis. Ann Surg Oncol 24:1392-1398. doi:10.1245/s10434-016-5709-y

12. Navarria P, Pessina F, Clerici E, Franceschini D, Gay LG, De Rose F, Renna I, D'Agostino G, Franzese C, Comito T, Tomatis S, Nibali MC, Leonetti A, Puglisi G, Bello L, Scorsetti M (2019) Surgery Followed by Hypofractionated Radiosurgery on the Tumor Bed in Oligometastatic Patients With Large Brain Metastases. Results of a Phase 2 Study. Int J Radiat Oncol Biol Phys 105:1095-1105. doi:10.1016/j.ijrobp.2019.08.054

13. Das P, Delclos ME, Skibber JM, Rodriguez-Bigas MA, Feig BW, Chang GJ, Eng C, Bedi M, Krishnan S, Crane CH (2010) Hyperfractionated accelerated radiotherapy for rectal cancer in patients with prior pelvic irradiation. Int J Radiat Oncol Biol Phys 77:60-65. doi:10.1016/j.ijrobp.2009.04.056

14. Marcrom SR, McDonald AM, Thompson JW, Popple RA, Riley KO, Markert JM, Willey CD, Bredel M, Fiveash JB (2017) Fractionated stereotactic radiation therapy for intact brain metastases. Adv Radiat Oncol 2:564-571. doi:10.1016/j.adro.2017.07.006

15. Eaton BR, LaRiviere MJ, Kim S, Prabhu RS, Patel K, Kandula S, Oyesiku N, Olson J, Curran W, Shu HK, Crocker I (2015) Hypofractionated radiosurgery has a better safety profile than single fraction radiosurgery for large resected brain metastases. J Neurooncol 123:103-111. doi:10.1007/s11060-015-1767-4

16. Inoue HK, Sato H, Seto K, Torikai K, Suzuki Y, Saitoh J, Noda SE, Nakano T (2014) Five-fraction CyberKnife radiotherapy for large brain metastases in critical areas: impact on the surrounding brain volumes circumscribed with a single dose equivalent of 14 Gy (V14) to avoid radiation necrosis. J Radiat Res 55:334-342. doi:10.1093/jrr/rrt127

17. Inoue HK, Seto K, Nozaki A, Torikai K, Suzuki Y, Saitoh J, Noda SE, Nakano T (2013) Three-fraction CyberKnife radiotherapy for brain metastases in critical areas: referring to the risk evaluating radiation necrosis and the surrounding brain volumes circumscribed with a single dose equivalence of 14 Gy (V14). J Radiat Res 54:727735. doi:10.1093/jrr/rrt006

18. Lin NU, Lee EQ, Aoyama H, Barani IJ, Barboriak DP, Baumert BG, Bendszus M, Brown PD, Camidge DR, Chang SM, Dancey J, de Vries EGE, Gaspar LE, Harris GJ, Hodi FS, Kalkanis SN, Linskey ME, Macdonald DR, Margolin K, Mehta MP, Schiff D, Soffietti R, Suh JH, van den Bent MJ, Vogelbaum MA, Wen PY (2015) Response assessment criteria for brain metastases: proposal from the RANO group. The Lancet Oncology 16:e270-e278. doi:10.1016/s1470-2045(15)70057-4

19. Kanda Y (2013) Investigation of the freely available easy-to-use software 'EZR' for medical statistics. Bone marrow transplantation 48:452-458. doi:10.1038/bmt.2012.244

20. Murai T, Ogino H, Manabe Y, Iwabuchi M, Okumura T, Matsushita Y, Tsuji Y, Suzuki H, Shibamoto Y (2014) Fractionated stereotactic radiotherapy using CyberKnife for the treatment of large brain metastases: a dose escalation study. Clin Oncol (R Coll Radiol) 26:151-158. doi:10.1016/j.clon.2013.11.027

21. Jeong WJ, Park JH, Lee EJ, Kim JH, Kim CJ, Cho YH (2015) Efficacy and Safety of Fractionated Stereotactic Radiosurgery for Large Brain Metastases. J Korean Neurosurg Soc 58:217-224. doi:10.3340/jkns.2015.58.3.217

22. Navarria P, Pessina F, Cozzi L, Ascolese AM, De Rose F, Fogliata A, Franzese C, Franceschini D, Tozzi A, D'Agostino G, Comito T, Iftode C, Maggi G, Reggiori G, Bello L, Scorsetti M (2016) Hypo-fractionated stereotactic radiotherapy alone using volumetric modulated arc therapy for patients with single, large brain metastases unsuitable for surgical resection. Radiat Oncol 11:76. doi:10.1186/s13014-016-0653-3

23. Minniti G, Scaringi C, Paolini S, Lanzetta G, Romano A, Cicone F, Osti M, Enrici RM, Esposito V (2016) SingleFraction Versus Multifraction ( $3 \times 9 \mathrm{~Gy}$ ) Stereotactic Radiosurgery for Large $(>2 \mathrm{~cm}$ ) Brain Metastases: A 
Comparative Analysis of Local Control and Risk of Radiation-Induced Brain Necrosis. Int J Radiat Oncol Biol Phys 95:1142-1148. doi:10.1016/j.jijrobp.2016.03.013

24. Mut M (2012) Surgical treatment of brain metastasis: a review. Clin Neurol Neurosurg 114:1-8. doi:10.1016/j.clineuro.2011.10.013

25. Noel G, Medioni J, Valery C-A, Boisserie G, Simon JM, Cornu P, Hasboun D, Ledu D, Tep B, Delattre J-Y, Marsault C, Baillet F, Mazeron J-J (2003) Three irradiation treatment options including radiosurgery for brain metastases from primary lung cancer. Lung Cancer 41:333-343. doi:10.1016/S0169-5002(03)00236-8

26. Amsbaugh M, Pan J, Yusuf MB, Dragun A, Dunlap N, Guan T, Boling W, Rai S, Woo S (2016) Dose-Volume Response Relationship for Brain Metastases Treated with Frameless Single-Fraction Linear Accelerator-Based Stereotactic Radiosurgery. Cureus 8:e587. doi:10.7759/cureus.587

27. Shaw E, Scott C, Souhami L, Dinapoli R, Kline R, Loeffler J, Farnan N (2000) Single dose radiosurgical treatment of recurrent previously irradiated primary brain tumors and brain metastases: final report of RTOG protocol $90-05$. Int J Radiat Oncol Biol Phys 47:291-298. doi:10.1016/s0360-3016(99)00507-6

28. Milano MT, Grimm J, Niemierko A, Soltys SG, Moiseenko V, Redmond KJ, Yorke E, Sahgal A, Xue J, Mahadevan A, Muacevic A, Marks LB, Kleinberg LR (2020) Single- and Multifraction Stereotactic Radiosurgery Dose/Volume Tolerances of the Brain. Int J Radiat Oncol Biol Phys. doi:10.1016/j.ijrobp.2020.08.013

\section{Figures}

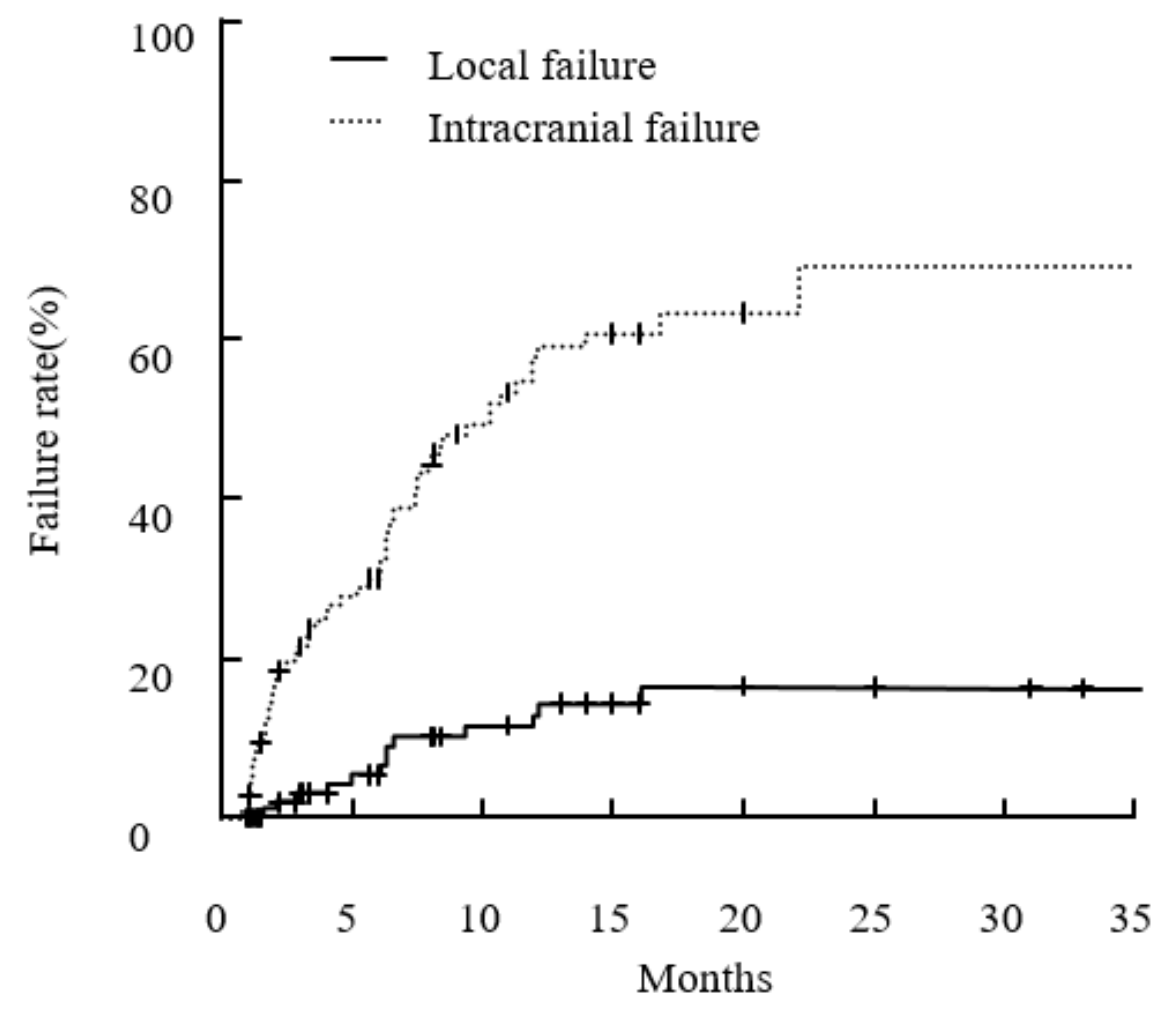

Figure 1

Cumulative incidence of local and intracranial failure rates 


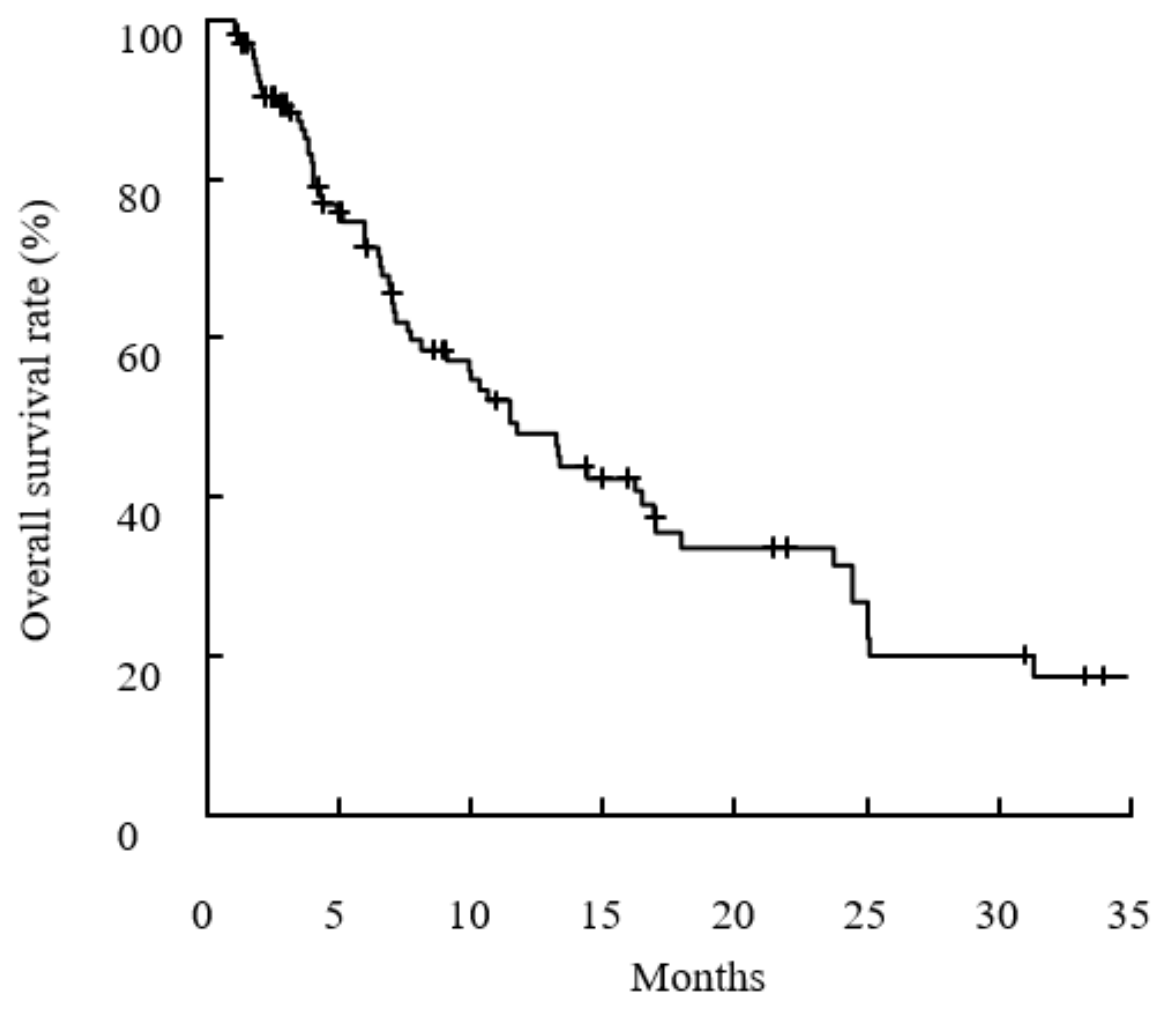

Figure 2

Kaplan-Meier curve of the overall survival rate

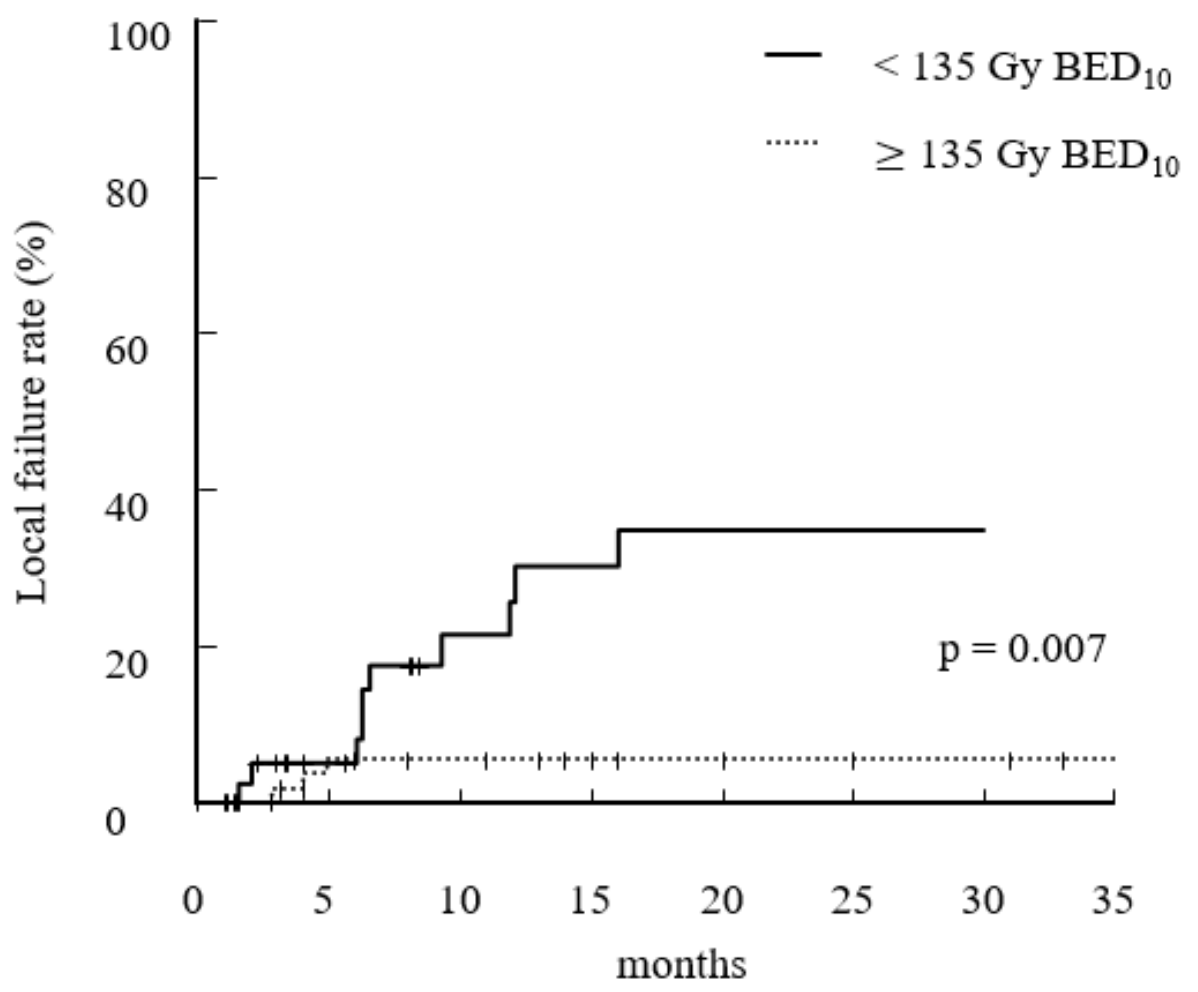

Figure 3 
Cumulative incidence of the local failure rate according to the maximum tumor dose

Page 14/14 